\title{
SURVIVAL OF RAT EMBRYOS AFTER FREEZING AND THAWING
}

\author{
D. G. WHITTINGHAM* \\ Physiological Laboratory, Downing Street, Cambridge CB2 $3 E G$
}

(Received 13th December 1974)

Survival of mammalian embryos after storage at sub-zero temperatures was first achieved in the mouse in which all the preimplantation stages were shown to survive storage at $-196^{\circ} \mathrm{C}$ when suitably cooled and thawed (Whittingham, Leibo \& Mazur, 1972; Wilmut, 1972; Whittingham, 1974a). Similar procedures have demonstrated that blastocysts of cattle (Wilmut \& Rowson, 1973), morulae and blastocysts of sheep (Willadsen, Polge, Rowson \& Moor, 1974) and four-cell, eight-cell and morulae of rabbits (Bank \& Maurer, 1973; Whittingham \& Adams, 1974) will survive storage at $-196^{\circ} \mathrm{C}$. This communication reports the survival of two-cell, four-cell and eight-cell rat embryos after storage at $-196^{\circ} \mathrm{C}$ for periods up to 3 months.

Superovulation of immature female rats, 26 to 28 days of age (CFHB random-bred strain, Carworth-Europe), with intraperitoneal injections of 25 i.u. PMSG and 10 i.u. HCG given 44 to $48 \mathrm{hr}$ apart produced large numbers of unfertilized oocytes or embryos retarded in development following successful mating which was detected by the presence of spermatozoa or a coital plug in the vagina. As a result of this finding, rat embryos were obtained from naturally mated mature females, 6 to 12 weeks of age, of the CFHB random-bred strain (Carworth-Europe). The day on which spermatozoa or a coital plug was found in the vagina was taken as Day 1 of pregnancy. Two-cell and four-cell embryos were flushed from the oviducts on the morning of Day 2 and Day 3, respectively, and eight-cell embryos were flushed from the oviduct and anterior portion of the uterine horn on Day 4 of pregnancy. Between ten and eighteen embryos were collected from each female. The embryos were collected in a standard culture medium for mouse embryos containing $94.59 \mathrm{~mm}-\mathrm{NaCl}, 4.78 \mathrm{~mm}-\mathrm{KCl}$, $1.71 \mathrm{~mm}-\mathrm{CaCl}_{2}, 1.19 \mathrm{~mm}-\mathrm{MgSO}_{4} .7 \mathrm{H}_{2} \mathrm{O}, 1.19 \mathrm{~mm}-\mathrm{KH}_{2} \mathrm{PO}_{4}, 25.07 \mathrm{~mm}-$ $\mathrm{NaHCO}_{3}, 23.28 \mathrm{~mm}-\mathrm{Na}$ lactate, $0.33 \mathrm{~mm}-\mathrm{Na}$ pyruvate, $5.56 \mathrm{~mm}$-glucose, 4 $\mathrm{mg}$ bovine serum albumin $/ \mathrm{ml}, 100$ Units penicillin $\mathrm{G}$ (potassium salt) $/ \mathrm{ml}$ and $50 \mu \mathrm{g}$ streptomycin sulphate $/ \mathrm{ml}$ (Whittingham, 1971). They were washed in two changes of medium and transferred to $0.1 \mathrm{ml}$ phosphate-buffered medium (PB1 : Whittingham \& Wales, 1969) contained in a glass culture tube $(12 \times 75$ $\mathrm{mm}$ ). The embryos were equilibrated with $1.5 \mathrm{M}$-dimethylsulphoxide (DMSO) at $0^{\circ} \mathrm{C}$ for $15 \mathrm{~min}$ by the addition of a further $0.1 \mathrm{ml} \mathrm{PBl}$ containing $3 \mathrm{M}$ DMSO. The procedures for freezing and thawing were similar to those used for mouse embryos and have been described elsewhere (Whittingham et al.,

\footnotetext{
* Present address: M.R.C. Mammalian Development Unit, University College London, Wolfson House, 4 Stephenson Way, London NW1 2HE.
} 
1972; Whittingham, 1974b). Various rates of cooling and thawing were studied. Upon thawing, the DMSO was diluted out in a step-wise manner with the culture medium for mouse embryos containing $10 \%$ fetal calf serum.

An initial assessment of survival was made by tabulating the proportion of embryos which appeared morphologically normal at recovery since, until rat embryos reach the late eight-cell stage, they do not develop continuously in vitro to the blastocyst stage (Mayer \& Fritz, 1974; Whittingham, 1975). In the mouse, there is a very close approximation between the number of embryos morphologically normal at recovery and the number that continue development to the blastocyst stage in vitro (Whittingham et al., 1972). The proportions of two-cell, four-cell and eight-cell rat embryos which appeared normal at recovery after cooling at various rates from $-5^{\circ} \mathrm{C}$ to $-80^{\circ} \mathrm{C}$ before transfer to liquid nitrogen at $-196^{\circ} \mathrm{C}$ are summarized in Table 1 . The range of effective

Table 1. Percentage survival of frozenthawed rat embryos cooled in $1.5 \mathrm{M}-\mathrm{DMSO}$ at various rates to $-80^{\circ} \mathrm{C}$, stored at $-196^{\circ} \mathrm{C}$ and thawed at approximately $5^{\circ} \mathrm{C} / \mathrm{min}$

\begin{tabular}{ccccc}
\hline \multirow{2}{*}{$\begin{array}{c}\text { Stage } \\
\text { of } \\
\text { embryo }\end{array}$} & \multicolumn{4}{c}{ Cooling rate $\left({ }^{\circ} \mathrm{C} / \mathrm{min}\right)$} \\
\cline { 2 - 5 } & $\sim 0.3$ & $\sim 0.6$ & 0.8 to 1.0 & $\sim 6.0$ \\
\hline Two-cell & $57^{*}$ & 71 & 84 & 2 \\
& $(5,58) \dagger$ & $(3,35)$ & $(5,51)$ & $(2,20)$ \\
Four-cell & - & 70 & - & - \\
& & $(4,67)$ & & \\
Eight-cell & 65 & 68 & 73 & 0 \\
& $(5,96)$ & $(3,32)$ & $(2,22)$ & $(1,20)$ \\
\hline
\end{tabular}

\footnotetext{
* $\%$ Survival $=$ number of embryos normal after thawing $\times 100 /$ total number of embryos recovered. + Figures in parentheses represent the number of replicates, and the number of embryos frozen.
}

cooling rates for survival was similar to that found for the mouse (Whittingham et al., 1972), an optimal rate being between 0.6 and $1.0^{\circ} \mathrm{C} / \mathrm{min}$. There was no difference in survival of embryos warmed at $5^{\circ} \mathrm{C} / \mathrm{min}$ (Table 1) and $24^{\circ} \mathrm{C} / \mathrm{min}$ (results not given), but none survived warming at $450^{\circ} \mathrm{C} / \mathrm{min}$, findings similar to those for the mouse.

After the morphological assessment of survival, the embryos were transferred to drops of medium plus $10 \%$ fetal calf serum in plastic Petri dishes with a paraffin oil overlay and were cultured at $37^{\circ} \mathrm{C}$ in $5 \% \mathrm{CO}_{2}$ in air (Brinster, 1963). The embryos were observed after 24 and $48 \mathrm{hr}$ in culture and the developmental stages reached at $48 \mathrm{hr}$ are summarized in Table 2. A small proportion of twocell embryos, normal at recovery, cleaved to the four-cell stage $(25 / 84,30 \%)$ after $24 \mathrm{hr}$ in vitro, but no further development took place. The four-cell embryos failed to cleave in culture but $61 \%(38 / 62)$ of the eight-cell embryos developed into morulae and blastocysts within $48 \mathrm{hr}$ in vitro. These findings are similar to the previous results reported for the culture of unfrozen rat embryos (Folstad, Bennett \& Dorfman, 1969; Mayer \& Fritz, 1974; Toyoda \& Chang, 
1974; Whittingham, 1975). Thus, even within the limits of assessing viability by continued development in vitro, there is a good indication that rat embryos survive storage at $-196^{\circ} \mathrm{C}$ when suitably cooled and thawed over a range of rates optimal for the preservation of mouse embryos.

Table 2. Development of frozen-thawed rat embryos in vitro

\begin{tabular}{lcccccccc}
\hline $\begin{array}{c}\text { Stage of } \\
\text { embryo } \\
\text { frozen }\end{array}$ & $\begin{array}{c}\text { No. recovered } \\
\text { no. frozen }\end{array}$ & $\begin{array}{c}\text { No. } \\
\text { normal } \\
(\%)\end{array}$ & $\begin{array}{c}\text { Duration of } \\
\text { culture }(\text { hr })\end{array}$ & Four-cell & Eight-cell & Morula & Blastocyst \\
\hline & & & & & & & & \\
Two-cell & $121 / 144$ & $84(69)$ & 48 & 25 & - & - & $\overline{-}$ \\
Four-cell & $55 / 67$ & $37(67)$ & 48 & 37 & $\overline{7}$ & $\overline{7}$ \\
Eight-cell* & $92 / 128$ & $62(65)$ & 48 & - & $24 \dagger$ & \\
\hline
\end{tabular}

* Only embryos cooled at $\sim 0.3$ and $\sim 0.6^{\circ} \mathrm{C} / \mathrm{min}$ (see Table 1) were cultured.

$\dagger$ Seventeen degenerated within the first $24 \mathrm{hr}$.

The final test of viability of the frozen-thawed rat embryos was made by transfer of the embryos immediately upon thawing to the oviducts of pseudopregnant recipients. Pseudopregnancy was induced in mature female rats by mechanical stimulation of the cervix in the evening of the day of pro-oestrus. Nineteen two-cell, twelve four-cell and thirty-three eight-cell embryos considered to be normal at recovery were transferred to the oviducts (three to six embryos/oviduct) of females on the afternoon following induction of pseudopregnancy. The females were examined on Day 18 of pregnancy; two apparently normal live fetuses $(11 \%)$ resulted from the transferred two-cell embryos, none from the four-cell and three apparently normal live fetuses $(9 \%)$ from the transferred eight-cell embryos. The over-all viability was low, but no comparison was made of the development of unfrozen rat embryos similarly transferred. The transfer of the eight-cell embryos to the uterus on Day 4 of pseudopregnancy might have increased survival. It is also possible that there was poor induction of pseudopregnancy by the method of cervical stimulation. Nevertheless, the results demonstrate that rat embryos survive storage at $-196^{\circ} \mathrm{C}$ and, although the viability is low compared with that in the mouse, it is anticipated that high rates of survival to term will be obtained after improvement of the methods for embryo culture, embryo transfer and induction of pseudopregnancy.

This work was supported by the Medical Research Council, U.K. I wish to acknowledge the expert technical assistance of Mrs J. Donaldson.

\section{REFERENCES}

Bank, H. \& MaUrer, R. R. (1973) Survival of frozen rabbit embryos. 7. Cryobiol. 10, 508.

BRINSTER, R. L. (1963) A method for in vitro cultivation of mouse ova from two-cell to blastocyst. Expl Cell Res. 32, 205-208.

Folstad, L., Bennett, J. P. \& Dorfman, R. I. (1969) The in vitro culture of rat ova. F. Reprod. Fert. 18, $145-146$.

MAYER, J. F. \& FrITz, H. I. (1974) The culture of preimplantation rat embryos and the production of allophenic rats. 7. Reprod. Fert. 39, 1-9.

Toyoda, Y. \& Chang, M. C. (1974) Fertilization of rat eggs in vitro by epididymal spermatozoa and the development of eggs following transfer. F. Reprod. Fert. 36, 9-22. 
Whittingham, D. G. (1971) Culture of mouse ova. 7. Reprod. Fert., Suppl. 14, 7-21.

Whitsingham, D. G. (1974a) The viability of frozen-thawed mouse blastocysts. 7. Reprod. Fert. 37, $159-162$.

Whittingham, D. G. (1974b) Embryo banks in the future of developmental genetics. Genetics, Princeton, 78, 395-402.

Whittingham, D. G. (1975) Fertilization, early development and storage of mammalian ova in vitro. In The Early Development of Mammals. Eds. M. Balls and A. E. Wild. Cambridge University Press. (In press).

Whittingham, D. G. \& Adams, C. E. (1974) Low temperature preservation of rabbit embryos. Proc. 11 th A. Meeting Soc. Cryobiol., London. Abstr. No. 75.

Whittingham, D. G., Leibo, S. P. \& Mazur, P. (1972) Survival of mouse embryos frozen to $-196^{\circ} \mathrm{C}$ and $-269^{\circ}$ C. Science, $\mathcal{N}$. r. $178,411-414$.

Whitringham, D. G. \& Wales, R. G. (1969) Storage of two-cell embryos in vitro. Aust. J. biol. Sci. 22, 1065-1068.

Willadsen, S. M., Polge, C., Rowson, L. E. A. \& Moor, R. M. (1974) Preservation of sheep embryos in liquid nitrogen. Proc. 11 th A. Meeting Soc. Cryobiol., London. Abstr. No. 73.

WiLmut, I. (1972) The effect of cooling rate, warming rate, cryoprotective agent and stage of development on survival of mouse embryos during freezing and thawing. Life Sciences, 11, 1071-1079.

Wilmut, I. \& Rowson, L. E. A. (1973) Experiments on the low-temperature preservation of cow embryos. Vet. Rec. 92, 686-690. 